\title{
Argentina in the Global Middle East. Lily Pearl Balloffet (Stanford, CA: Stanford University Press, 2020). Pp. 248. $\$ 90.00$ cloth. ISBN: 9781503611740 - Corrigendum
}

Nadim Bawalsa

DOI: https://doi.org/10.1017/S002074382100057X; Published online by Cambridge University Press 06 July 2021

In the initial publication of Bawalsa (2021), Lily Pearl Balloffet's name was printed incorrectly. The original review has been corrected to include the author's full name.

The reviewer apologizes for this error.

\section{Reference}

Bawalsa, Nadim. "Argentina in the Global Middle East. Lily Balloffett (Stanford, CA: Stanford University Press, 2020). Pp. 248. $\$ 90.00$ Cloth. ISBN: 9781503611740.” International Journal of Middle East Studies 53, no. 3 (2021): 564-66. doi:10.1017/ S002074382100057X.

Cite this article: Bawalsa N (2021). Argentina in the Global Middle East. Lily Pearl Balloffet (Stanford, CA: Stanford University Press, 2020). Pp. 248. $\$ 90.00$ cloth. ISBN: 9781503611740 - Corrigendum. International Journal of Middle East Studies 53, 729-729. https://doi.org/10.1017/S002074382100101X

(C) The Author(s), 2021. Published by Cambridge University Press 